\title{
Selection, management and use of cocksfoot cultivars in North Island pastoral farming
}

S.C. MOLONEY

Grassline $^{\circledR}$ Adviser, AgResearch Grasslands, Private Bag 11008, Palmerston North

\begin{abstract}
Cocksfoot (Dactylis glomerata) is the second most commonly sown grass species after ryegrass in New Zealand farming. In 1980, Grasslands Apanui was replaced by two new but very different cocksfoot cultivars characterised by improved digestibility and rust tolerance, cool-season growth and greater persistence. Grasslands Wana, semiprostrate and densely tillered, was developed for dryland pastures of low soil fertility heavily set stocked by sheep. Grasslands Kara, of low tiller density and open structure, was developed for lowland pastures of higher soil fertility as a companion to other tufted grass species to be rotationally grazed. Despite the different intended uses for the two cultivars, Wana was widely used in all environments. As a consequence, many farmers have been disappointed with the dominance of by Wana, particularly in lowland pastures of medium to high fertility where important companion grasses and clover have been suppressed, leading to poor pasture palatability. This paper describes key cultivar differences and discusses their implications for North Island farming systems, using the results of two on-farm trials to demonstrate cultivar and management effects. Guidelines on sowing rates, cultivar selection and management techniques for avoiding and reversing cocksfoot dominance are provided.
\end{abstract}

Keywords: cool-season production, Dactylis glomerata, dominance, Grasslands Wana, Grasslands Kara, 'target cocksfoot percentage', lowland

\section{Introduction}

In New Zealand agriculture there has been a long history of including the grass species cocksfoot (Dactylis glomerata) in pasture mixtures (Levy 1951). Seed production of English varieties began on Banks Peninsula in 1853, with 14500 ha grown for seed by 1900 (66\% from Banks Peninsula) (Coulson 1979). Next to perennial ryegrass, cocksfoot is the second most commonly sown species in New Zealand (Barker et al. 1985) and is used on $57 \%$ of all sheep farms
(Sangakkara et al. 1982). Relative to ryegrass, cocksfoot provides reliable leafy summer growth free of endophyte, with greater persistency in dryland and grass grub-affected regions. Grasslands Apanui, the first cocksfoot cultivar bred and certified (1953) in New Zealand, was used extensively over the 1960-70s, but gained a reputation for being erect and clumpy, and having poor palatability, high rust susceptibility and poor persistence under sheep grazing.

To address these problems, two breeding programmes based on mediterranean plant material resulted in the certification of Grasslands Wana suited to drland pastures of low soil fertility, set stocked by sheep (Rumba11 1982b). Grasslands Kara cocksfoot was developed for rotationally grazed cattle pastures, where it could be mixed with other tufted grass species such as ryegrass (Rumball 1982a). Despite both cultivars being released in 1980 and sharing similar improvements of greater rust resistance, digestibility, cool-season and annual yield, they were developed for very different environments and uses.

\section{Cultivar features and differences}

These different roles were a direct result of their inherent morphological differences (Table 1). Wana, selected entirely from north-western Spanish material, is low-crowned, densely tillered, light green and fine leaved with excellent stem and stripe rust resistance (Puccinia graminis, P. striiformis). Kara, developed as a hybrid between a tetraploid of the Portuguese subspecies ( $D$. glomerata ssp. lusitanica), and Apanui (Dactylis glomerata L.), is taller, more erect with a much lower tiller density, longer broader leaves and bluish green.

Stevens et al. (1992) reported that relative to Wana cocksfoot, Kara had greater seedling vigour, better winter brown stripe (Scolicotrichum graminis) tolerance and less frost tenderness. In Southland Kara had twice the winter growth of Wana and significantly better early-spring recovery. Stevens et al. (1992) also found that in spring Kara, relative to Nui ryegrass (Lolium perenne L.), had higher crude protein (CP\%) but lower dry matter digestibility (DMD\%), but in summer and autumn no differences occurred. The other cocksfoot cultivar commercially available in New Zealand is Saborto. Bred in the UK, Saborto has Portuguese parentage and features similar to that of Kara (Table 1). 
Table 1 Features of cocksfoot cultivars commercially available in New Zealand

\begin{tabular}{c|c|c|c|c|c}
\hline Cultiiar & Habit & Tiller density and size & $\begin{array}{c}\text { Stem \& stripe rust } \\
\text { tolerance }\end{array}$ & Cool-season growth & Early- spring growth \\
\hline Wana & $\begin{array}{c}\text { semi-erect, short } \\
\text { fine leaves } \\
\text { Karect, tall, broad } \\
\text { leaves } \\
\text { very erect, tall, } \\
\text { Sery broad leaves }\end{array}$ & $\begin{array}{c}\text { very high } \\
\left(7-11,000 / \mathrm{m}^{2}\right), \text { small } \\
\text { low } \& \text { large } \\
\left(1-5,000 / \mathrm{m}^{2}\right) \\
\text { very low \&large }\end{array}$ & very high & moderate-high & moderate \\
moderate & very high high & high & very high \\
\hline
\end{tabular}

Two on-farm evaluations of Grasslands Wana and Kara

\section{Trial one: Wana cocksfoot, coastal Wairarapa}

Moloney (1991) followed the yield and composition trends of a Wana cocksfoot mixture sown in 1981 at Castlepoint Station in coastal Wairarapa. The site was a high fertility valley floor paddock predominantly rotationally grazed with sheep. The pasture mixture was autumn sown and included Grasslands Roa tall fescue (Festuca arundinacea Schreb.) (22 kg/ha), Wana cocksfoot (9 kg/ha), Grasslands Puna chicory (Cichorium intybus L. (3 kg/ha) and Grasslands Huia white clover (Trifolium repens L.) (3 kg/ha). The main objective of this pasture mixture was to increase the quantity and quality of summer pasture yield and at the same time provide pasture free of ryegrass staggers (RGS). Measurements were taken on both the Wana and a conventional Ruanui ryegrass Huia white clover pasture, from 1983 to 1987 (Moloney 1991). The high sowing rate of cocksfoot relative to tall fescue (1125 vs 880 seeds $/ \mathrm{m}^{2)}$ was probably also a factor in the Wana dominance at this site (Table 5).

Wana dominated total dry matter (TDM) by year 2 (64\%) increasing to a peak $(75 \%)$ in the fourth year (Table 2). White clover and tall fescue were very much secondary species over this period at $8 \%$ and $4 \%$ of TDM respectively. In 1986, winter pugging damage by weaner cattle caused a marked decline in Wana from $72 \%$ to $30 \%$ TDM in spring 1986. This had the immediate effect of releasing Roa tall fescue which increased from $9 \%$ (winter 1986) to $21 \%$ of TDM by spring 1986. Wana also appeared to suppress both white clover (Table 2) and sub clover ( $T$. subterraneum) yield. In later sowings at the same site, Wana was sown with high endophyte ryegrass. Although these pastures also became cocksfoot dominant, the process was slower than with the less competitive companion species tall fescue (SC. Moloney unpub. data).

Despite the Wana dominance, the Wana/Roa pasture outproduced the ryegrass/white clover control pasture by 1.4 tha annually, yielding an extra $11 \mathrm{~kg} \mathrm{DM} / \mathrm{ha} /$ day
Table 2 Trial I, mean annual composition of Wana cocksfoot in a lowland pasture mixture at Castlepoint, Wairarapa (data expressed as \% of TDM). Pasture sown March 1981.

\begin{tabular}{ccccc}
\hline Year & Cocksfoot & Tall fescue & Chicory & White \\
\hline 1903 & 64.3 & 4.7 & 12 & 7.9 \\
1964 & 70.0 & 4.5 & 4.3 & 7.4 \\
1965 & 75.3 & 3.7 & 1.4 & 0.9 \\
1966 & 51.6 & 13.7 & 0.4 & 14.3 \\
1967 & 50.2 & 22.6 & 1.3 & 0.0 \\
\hline
\end{tabular}

(34\%) over summer and $4 \mathrm{~kg}$ DM/ha/day over autumn (Moloney 1991).

\section{Trial 2: Kara cocksfoot, Central Plateau}

Constraints to pasture supply on pumice soils of the Central Plateau are poor cool-season growth and grass grub (Costelytra zealandica) damage. Kara cocksfoot was chosen as the most suitable cultivar that would mix well with Roa tall fescue in a rotationally grazed dairy pasture (Rumball 1982a). A pasture mixture of Roa tall fescue $(20 \mathrm{~kg} / \mathrm{ha})$, Kara cocksfoot $(6 \mathrm{~kg} / \mathrm{ha})$, Puna chicory ( $1 \mathrm{~kg} / \mathrm{ha}$ ) and Grasslands Pitau white clover (3 kg/ha) was sown on the intensively managed dairy unit of David Martin, north west of Taupo in 1986 (Moloney 1991).

In the first year (Table 3) Kara dominated the mixture, by the second it was equal to Roa but by the third year Roa dominated (54\% v. 20\% of TDM). This sudden change in composition can be explained by: a high sowing rate of cocksfoot relative to tall fescue

Table 3 Trial 2, mean annual composition of Kara cocksfoot in an intensively grazed, lowland pasture mixture at Atiamuri, Taupo (data are expressed as \% of TDM). Pasture sown October 1986.

\begin{tabular}{ccccc}
\hline Year & Cocksfoot & Tall fescue & Chicory & White clover \\
\hline 1907 & 46.6 & 16.7 & 0.0 & 13.1 \\
1900 & 32.7 & 39.2 & 2.4 & 0.7 \\
1989 & 21.2 & 53.9 & 0.0 & 7.5 \\
\hline
\end{tabular}


(600 v. 800 seeds $/ \mathrm{m}^{2}$ respectively - ideally this should have been 200 v. 800) (Tables 4 and 5); long rotation lengths in the first year particularly over autumn and winter; and an increase in the amount of nitrogen applied (from 50 to $90 \mathrm{~kg} \mathrm{~N} / \mathrm{ha} /$ year), which would have favoured tall fescue (Moloney et al. 1993).

The average annual production of this pasture relative to a ryegrass/white clover pasture (Ellett and Huia) was $3.7 \mathrm{tDM} / \mathrm{ha}$ more, with $+14 \mathrm{~kg} \mathrm{DM} / \mathrm{ha} /$ day $($ or $+22 \%)$ in spring and $+17 \mathrm{~kg} \mathrm{DM} / \mathrm{ha} /$ day $(+29 \%)$ in summer (Moloney 1991).

\section{Discussion}

\section{Wana cocksfoot}

Wana has been widely used in intensive and extensive lowland pasture mixtures in both the North and South Islands.' Regional use in the North Island has been greatest in the dryland east coast (Belgrave et al. 1990). Outside this region, use has ranged from intensive dairying to semi-extensive sheep and cattle breeding.

Perennial ryegrass and white clover have been the common companion species sown with Wana. Others species have included tall fescue (Festuca arundinacea Schreb.), phalaris (Phalaris aquatica L.) and red clover (Trifolium pratense L.) (Korte et al. 1992).

In a large number of these mixtures, farmers, researchers and advisors have observed that Wana has become the dominant grass species after the second and third year (Korte et al. 1992; Smith et al. 1993; Milne et al. 1993). The results from trial 1 (Table 2) are typical of how Wana's aggressive nature can restrict important contributions from higher quality companion species such as tall fescue and white clover. Wana dominance has also occurred in regions with adequate summer moisture (e.g., Central Plateau and Bay of Plenty), because of poor soil fertility (nitrogen), grass grub and low ryegrass persistence. This dominance of Wana over other tufted grass companion species and white clover was cited by Rumball (1982b) as a potential problem with Wana. Rumball (1982b) intended Wana to provide improved summer yield and persistence in low fertility dryland environments with moderate to severe grazing pressure.

Long-term measurements in the Manawatu suggest that Wana dominance is cyclic and that from year 6 to 10 the clumps break down. This process is typical of many tufted perennial grass species, including ryegrass, but with cocksfoot the process takes considerably longer, particularly under low soil fertility (J.L. Brock unpub. data).

A second concern expressed by farmers and some researchers (Edwards \& Lucas 1993) is that Wana cocksfoot has low palatability (or animal acceptbility).
Barker et al. (1993a) showed that Wana had the lowest DMD\% (one measure of plant quality) compared with ryegrass, tall fescue, Grasslands Matua prairie grass (Bromus willdenowii Kunth) and phalaris. However, in dryland environments in the middle of summer, Wana, unlike ryegrass, provides leafy green forage which is free of rust and RGS.

Another measure of quality is crude protein $(\mathrm{CP} \%)$ which is directly linked to plant access to mineralised soil nitrogen. Lamb growth rate trials by $T$. Fraser and D. Poppi (pers. comm.) showed that on pure Wana pastures (i.e., no clover) which received $150 \mathrm{~kg} \mathrm{~N} / \mathrm{ha}$ year, liveweight gains of $225 \mathrm{~g} / \mathrm{head} /$ day could be achieved. This compared favourably with nil and high endophyte ryegrasses at $220 \mathrm{~g}$ and $160 \mathrm{~g} / \mathrm{head} / \mathrm{day}$, respectively.

This is an important observation and may help to explain why some farmers can experience palatability and performance problems, particularly with lambs. Poor clover yields in Wana-dominant pastures restrict animal dietary crude protein (Table 2). Other factors which further compromise white clover association with cocksfoot cultivars generally include grass grub (McCallum 1990), low soil fertility and low summer rainfall (Korte et al. 1992).

However, Wana's aggressive habit, lower fertility requirement and persistence make it well suited to steep and moderately steep hill country (Barker et al. 1985). Barker $\boldsymbol{e t}$ al. $(1988,1991,1993)$ and Moloney $\boldsymbol{e t}$ al. (1993) have found Wana to have wide application across both dry and moist hill country sites of low and medium fertility.

Despite slow establishment, Wana was the most persistent of the four alternative species to ryegrass and at most sites more productive than the resident pasture, particularly in the more extreme sites of North Canterbury and Tekapo (Barker et al. 1993). Webby et al. (1990) found that Wana oversown (with the aid of herbicide) into hill country complemented Ellett ryegrass well, increasing summer and autumn dry matter yield and, accordingly, carrying capacity and animal performance.

\section{Kara cocksfoot}

Although Kara was released at the same time as Wana (Rumball 1982a), only in the last 3-4 years has Kara had significant commercial use, possibly due to a combination of difficult seed production characteristics (Rumball 1982a) and less marketing compared with Wana. But is steadily increasing as farmers experience the advantages of a less aggressive cocksfoot cultivar.

In the second trial, north west of Taupo (Table 3), initial cocksfoot dominance by Kara was reversed by year three, tall fescue becoming the primary grass 
species. This reversal was due to a combination of management and soil fertility factors: a shorter rotation length, better utilisation and increased use of nitrogen (from 50 to $90 \mathrm{~kg} \mathrm{~N} / \mathrm{ha} / \mathrm{year}$ ). McCallum et al. (1990) found that the TDM response of cocksfoot to nitrogen was $9 \%$ and tall fescue 26\%. In the Central Plateau on pumice soils, Moloney et al. (1993) measured a 5-year mean sown grass (i.e. not TDM) response to nitrogen of ryegrass $22 \%$, cocksfoot $25 \%$ (14.6 kg DM/ha per $\mathrm{kg} \mathrm{N} / \mathrm{ha}$ ), phalaris $34 \%$ and tall fescue $91 \%$ (or $38 \mathrm{~kg}$ $\mathrm{DM} / \mathrm{ha}$ per $\mathrm{kg} \mathrm{N} / \mathrm{ha}$ ). These large differences in response efficiency to applied nitrogen demonstrate the potential to manipulate species composition in pasture. Had Wana been used in this mixture, this reversal would have been slower.

Another important influence on species composition in mixtures is grazing management. Lancashire \& Brock (1982) found major differences between cocksfoot cultivars in a high-fertility, sheep-grazed farrnlet trial in Manawatu. Three years after sowing with Matua prairie grass, ryegrass, Puna chicory and red clover and white clover, Wana and Kara cocksfoot performed similarly under RG (rotational grazing) (50\% TDM), although Wana had $39 \%$ more tillers $/ \mathrm{m}^{2}$. Under treatment $\mathrm{C}$ (combination, RG \& spring SS) Wana was 52\% and Kara $25 \%$ of TDM, while under SS (set stocking), Wana was $18 \%$ of TDM and Kara only $\mathbf{5 \%}$, with tiller densities of 11000 and 1300 tillers $/ \mathrm{m}^{2}$ respectively. Under these contrasting managements the structural differences between the two cultivars was very evident, with Wana's densely tillered, semi-prostrate habit (Table 1) much more suited to set stocking than Kara.

This structural difference gives Kara the capacity to complement other tufted grass species and white clover in pasture mixtures for flat and lowland environments of medium to high soil fertility. Experience has shown that in most North Island regions, Wana cocksfoot does not offer this opportunity. Milne et al. (1993). Smith et al. (1993) both reported Kara to be less aggressive relative to Wana in pasture mixtures sown in the North Island East Coast Pasture Demonstration Programme.

Should Wana cocksfoot continue to be used in lowland pasture mixtures of medium to high fertility in the North Island ahead of Kara cocksfoot, the benefits from using higher quality companion species such as white clover, tall fescue and ryegrass will largely be lost.

\section{Conclusions}

1. Modem cocksfoot cultivars remain an important component of most pasture mixtures, providing reliable additional summer and autumn yield, insect pest tolerance and a reduction in animal intake of fungal toxins, e.g., lolitrem $\mathrm{B}$, sporidesmin.

2. Considerable gains made in plant breeding have provided a better range of cultivars, all with improved cool-season yield, digestibility and rust tolerance.

3. It is crucial for farmers and advisers to select the correct cocksfoot cultivar to match the environment, grazing management and companion species selected.

4. Grasslands Wana can be very aggressive in most lowland pastures, resulting in cocksfoot dominance. However, researchers have found these same features make Wana ideally suited for moderate to steep hill country of low to medium fertility, of both sunny and shady aspect.

5. Grasslands Kara cocksfoot has been found to be much more compatible with companion grass species such as tall fescue, Grasslands Gala grazing brome (Bromus stamineus), phalaris, ryegrass and Matua prairie grass. This is particularly true in rotationally grazed cattle swards of medium to high fertility, where it gives significantly more coolseason and early-spring growth.

6. There is still a need for a semi-erect cultivar with medium tiller density (tending towards the Kara cocksfoot type) which will be a suitable companion to ryegrass and other grass species used in semiextensive lowland pastures of medium fertility grazed by sheep. 


\section{Appendix}

\section{Cocksfoot management}

\section{Avoiding cocksfoot dominance}

In avoiding cocksfoot dominance in lowland pasture mixtures of medium to high fertility, the following have been identified as critical factors.

\section{Pre-sowing}

1. Select the right cultivar for your livestock system and class of country (Table 4).

2. Ensure that the cultivar selected is sown in the right proportion to the other grass components in the mixture (Tables 4 \& 5).
3. Ensure that the other grass and clover components selected are all suitable for the environment and intended management (i.e., persistent).

\section{Post-sowing}

1. Control rotation length and post-grazing residual height in early summer. At this time long rotations and long residuals can result in rank growth and high rust incidence, resulting in poor feed quality and utilisation.

2. Control rotation length (particularly erect cultivars such as Kara) over autumn, winter and early spring. Keep post-grazing residuals to a minimum in the early autumn and late winter. Do not use autumn

Table 4: Choosing the right cocksfwt cultivar, companion species and sowing rates, for use in lowland pasture mixtures, and determining the target cocksfoot \%. (Note: This information is intended as a guide only)

\begin{tabular}{|c|c|c|c|c|}
\hline $\begin{array}{ll}\text { Grazing system } \\
\end{array}$ & Suitable cultivar & $\begin{array}{l}\text { Companion grass } \\
\text { species }\end{array}$ & $\begin{array}{l}\text { Target } \\
\text { cocksfoot } \% \\
\text { composition }\end{array}$ & $\begin{array}{c}\text { Sowing rate } \\
\text { (kg/ha) }\end{array}$ \\
\hline $\begin{array}{l}\text { Semi-extensive, rotational \& set-stocked } \\
\text { predominantly sheep, lowland pasture } \\
\text { Intensive sheep \& beef, } 70 \% \text { rotationally grazed } \\
\text { Cattle finishing rotationally grazed } \\
\text { Dryland Dairying }\end{array}$ & $\begin{array}{l}\text { New cultivar? } \\
\text { Kara } \\
\text { Kara/Saborto } \\
\text { Kara/Saborto }\end{array}$ & $\begin{array}{c}\text { ryegrass, or tall fescue, } \\
\text { or Gala \& phalaris } \\
\\
\\
\end{array}$ & $\begin{array}{l}3555 \% \\
30-40 \% \\
1530 \% \\
1025 \%\end{array}$ & 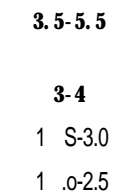 \\
\hline
\end{tabular}

Note: Sowing rates are based on a $7.5 \mathrm{~cm}$ row spacing at sowing. Reduce by $20 \%$ for a $15 \mathrm{~cm}$ row spacing. ? Cultivar is intended as the basis for a new cocksfoot cultivar (refer to conclusions).

Table 5: To calculate the sowing rates of individual components including cocksfwt in pasture mixtures, use the example shown in this table by altering the target \% composition.

\begin{tabular}{|c|c|c|c|c|}
\hline $\begin{array}{l}\text { Grass Component Target } \% \\
\text { Composition } \\
\text { A }\end{array}$ & $\begin{array}{c}\text { Pure pasture sowing } \\
\text { rates }(\mathrm{kg} / \mathrm{ha}) \\
B\end{array}$ & $\begin{array}{c}\text { Mixture components } \\
\text { sowing rate } \\
\text { [BXA] }\end{array}$ & $\begin{array}{c}\text { Species } 1000 \quad \text { seed } \\
\text { weights (g) \# }\end{array}$ & Seeds $/ \mathrm{m}^{2}$ \\
\hline ryegrass & 16 & 10.6 & 2.0 & 540 \\
\hline cocksfoot & 10 & 2.5 & $1.0 *^{*}$ & 250 \\
\hline phalaris & 12 . & 1.0 & 2.0 & 90 \\
\hline white clover & & $3-4$ & 0.7 & 490 \\
\hline red clover & & $2-3,(4-6), \square$ & 1.9 & 125 \\
\hline Totals & & $21.1 \mathrm{~kg} / \mathrm{ha}$ & & 1495 \\
\hline
\end{tabular}

Notes: Sowing rates are based on a $7.5 \mathrm{~cm}$ row spacing at sowing. Reduce by $20-25 \%$ for a $15 \mathrm{~cm}$ row spacing.

Tall fescue's target $\%$ composition is $70 \%$ and the pure pasture sowing rate is $26 \mathrm{~kg} / \mathrm{ha}$, therefore it should be used at $18-20$ $\mathrm{kg} / \mathrm{ha}$.

This is a theoretical sowing rate for phalaris. as it should not be sown as a pure pasture

.' Diploid red clover cultivars (e.g. Grasslands Colenso) are generally sown at a lower rate $(2-3 \mathrm{~kg} / \mathrm{ha})$ than tetraploid cultivars such as Grasslands Pawera (4-6 kg/ha)

- ** Wana cocksfoot has an average 1000 seed weight of $0.6 \mathrm{~g}$, while Kara is $1.0 \mathrm{~g}$

\# Charlton (1991) provides a full list of forage species, 1000 seed weights. 
saved pasture (ASP) management on Kara cocksfoot mixtures. These pastures have a high capacity for autumn and winter growth, particularly when nitrogen is applied in autumn. By storing pasture in situ (standing), potential yield and quality are substantially reduced, and dominance over companion grasses encouraged.

\section{How to reduce existing cocksfoot dominance}

Where dominance has already occurred, and problems of young stock (lambs) acceptability are being experienced, the following management techniques can be applied to release the companion grass species in a tall fescue or a ryegrass pasture.

1. Practice large scale and regular mob-stocking over the winter to very low post-grazing residuals. Deliberate and brief pugging damage may sometimes be necessary. This may have to be repeated in subsequent winters depending the degree of damage and recovery.

2. Apply early-autumn nitrogen (25-35 kg N/ha) and increase the annual use of nitrogen to favour companion grasses, particularly tall fescue.
3. Pastures should be grazed more closely, with rotation lengths shortened over the autumn, winter and early spring. Use breeding stock to periodically hard graze pastures in preparation for finishing or replacement stock.

\section{Calculating the right sowing rate proportions in a mixture}

Table 5 provides a guide to calculating the right sowing rates of various grass species in the pasture mixture (i.e., target grass species \% composition). This table should be used in conjunction with Table 4 which sets out suggested target cocksfoot \% composition for different grazing livestock systems.

Pasture for finishing and lactating Red deer should not include cocksfoot (or high endophyte ryegrass) in the mixture. Deer have been observed to ignore cocksfoot in preference for other species, e.g., tall fescue, bromes and clovers (Hunt \& Hay 1989).

\section{ACKNOWLEDGEMENTS}

The author wishes to thank Mr J.L. Brock, AgResearch for his invaluable comments on this paper.

\section{REFERENCES}

Barker, D.J.; Lancashire, J.A.; Meurk, C. 1985. 'Grasslands Wana' Cocksfoot - an improved grass suitable for hill country. Proceedings of the New Zealand Grassland Association 46: 167-I 72.

Barker, D.J.; Anderson, C.B.; Dymock, N. 1991. 'Grasslands Wana' cocksfoot persistence and autumn/winter production in hill country, under contrasting managements and micro-topographies. New Zealand journal of agricultural research 34: 25-30.

Barker, D.J.; Chapman, D.F.; Anderson, C.B.; Dymock, N. 1988. Oversowing 'Grasslands Wana' cocksfoot, 'Grasslands Maru' phalaris, and 'Grasslands Tahora' white clover in hill country at varying rates of paraquat and glyphosate. New Zealand journal of agricultural research 31: 373-382.

Barker, D.J.; Lancashire, J.A.; Moloney, S.C.; Dymock, N.; Stevens, D.R.; Turner, J.D.; Scott, D.; Archie, W.J. 1993. Introduction, production, and persistence of five grass species in dry hill country, 8. Summary and conclusions. New Zealand journal of agricultural research 36: 61-66.

Belgrave, B.E.; Watt PC.; Wewela S.; Sedcole J.R. 1990. A survey of farmer knowledge and use of pasture cultivars in New Zealand. New Zealand journal of agricultural research 33: 199-211.

Charlton, J.F.L. 1991. Some basic concepts of pasture seed mixtures for New Zealand farms. Proceedings of the New Zealand Grassland Association 53: 3740.

Coulson, J. 1979. Golden Harvest. Grass seeding days on Banks Peninsula. The Dunmore Press Ltd, Palmerston North, New Zealand.

Edwards, G. R.; Lucas, R.J.; Johnson, M. R. 1993. Grazing preference for pasture species by sheep is affected by endophyte and nitrogen fertility. Proceedings of the New Zealand Grassland Association 55: (this volume).

Hunt, W.F.; Hay, R.J.M. 1989. Alternative pastures for deer production in the Waikato. Proceedings of the Ruakura Deer Industry Conference: 31-33.

Korte, C.J.; Smith, D.R.; Slay, M.W.A.; Gray, M.H.; Quilter, S.J. 1992. Summary report for farmers on a survey of East Coast drought tolerant pastures. AgResearch report.

Lancashire, J.A.; Brock, J.L. 1983. Management of new cultivars for dryland. Proceedings of the New Zealand Grassland Association 44: 61-73.

Levy, E.B. 1951. The grasslands of New Zealand. Wellington, Government Printer. 
McCallum, D.A.; Thomson, N.A.; Roberts, A.H.C. 1990. Grass grub tolerant grasses and fertiliser nitrogen as an alternative to white clover in pastures subject to grass grub attack. Proceedings of the New Zealand Grassland Association 51: 105- 107.

Milne, G.D.; Moloney, S.C.; Smith, D.R. 1993. Demonstration of dryland species on 90 east coats North Island farms. Proceedings of the New Zealand Grassland Association 55: (this volume).

Moloney, S.C. 1991. Performance of tall fescue, cocksfoot and phalaris compared with perennial ryegrass, in on-farm trials. Proceedings of the New Zealand Grassland Association 53: 41-46.

Moloney, S.C.; Lancashire, J.A.; Barker, D.J. 1993. Introduction, production and persistence of five grass species in dry hill country, 7. Central Plateau, North Island, New Zealand. New Zealand journal of agricultural research 36: 49-60.

Rumball, W. 1982a. 'Grasslands Kara' cocksfoot (Dactylis glomerata L.). New Zealand journal of experimental agriculture 10:49-50

Rumball, W. 1982b. 'Grasslands Wana' cocksfoot
(Dactylis glomerata L.). New Zealand journal of experimental agriculture 10: 5 1-52

Rumball, W. 1983. Breeding for dryland farming. Proceedings of the New Zealand Grassland Association 44: 56-60.

Sangakkara, R.; Roberts E.; Watkin, B.R. 1982. Grass species used and pasture establishment practices in central North Island. New Zealand journal of experimental agriculture 10: 359-364.

Smith, D.R.; Slay, M.W.A.; Gray, M.H.; Milne, G.D. 1993. On-farm establishment of drought tolerant pastures on east coast of the North Island. Proceedings of the New Zealand Grassland Association 55: (this volume).

Stevens, D.R.; Baxter, G.S.; Stewart, A.V.; Casey, M.J.; Miller, K.B. 1992. Grasslands Kara cocksfoot: a productive cultivar under lax grazing. Proceedings of the New Zealand Grassland Association 54: 143146.

Webby, R.W.; Sheath, G.W.; Boom, C.J. 1990. Performance of new cultivars in a hill country finishing system. Proceedings of the New Zealand Grassland Association 51: $151 \cdot 155$. 